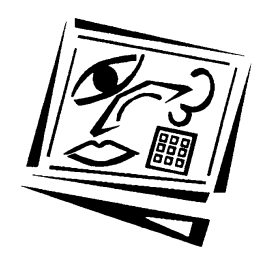

\title{
Can Web 2.0 technology assist college students in learning English writing? Integrating Facebook and peer assessment with blended learning
}

\author{
Ru-Chu Shih \\ National Pingtung University of Science and Technology
}

\begin{abstract}
The goal of this study was to investigate the effect of integrating Facebook and peer assessment with college English writing class instruction through a blended teaching approach. This blended approach consisted of one-third of a semester of classroom instruction and two-thirds of a semester combining Facebook, peer assessment, and classroom instruction. The subjects were 23 first-year students majoring in English at a technological university in Taiwan participating in an 18 week English writing class. The students were divided into three groups with three Facebook platforms. Both quantitative and qualitative approaches were employed in the study. Research instruments included pre-test and post-test of English writing skills, a self-developed survey questionnaire, and in-depth student interviews. The findings suggest that incorporating peer assessment using Facebook in learning English writing can be interesting and effective for college-level English writing classes. Students can improve their English writing skills and knowledge not only from the in-class instruction but also from cooperative learning. In addition, this Facebook integrated instruction can significantly enhance students' interest and motivation. Finally, the findings may provide useful instructional strategies for teachers of ESL English writing courses.
\end{abstract}

\section{Introduction}

The development and application of Web 2.0 technologies, such as blogs, online discussion boards, Flickr, YouTube, MySpace, Facebook, and others, have increased in popularity in recent years. These new applications allow users to interact and collaborate with each other via social media in a virtual community (McCarthy, 2010). As its official website states, Facebook is giving people the power to share and making the world more open and connected. By June, 2011, more than 500 million active users were using Facebook to communicate, interact, and socialise with each other (Facebook, 2011). The primary features of Facebook, including "wall", "info", "blog", "friends", "like", "unlike", "comment", "poke", "send message", "share photos", "links", and "video" provide users with a variety of means to communicate and interact with each other and to make new friends all over the world. In particular, the "share status" feature plays an important role in Facebook activities. People can almost instantly discuss and share all types of information and knowledge through the share status function, which is similar to an online discussion board. Student interactions in online discussions can facilitate a learner-centred approach to teaching and provide students with an opportunity to practise and learn knowledge and skills in a supportive and encouraging environment (Stacey, 2002; Birch \& Volkov, 2007; Moore \& Iida, 2010). In addition, in an online environment, students can communicate and interact with others 
at their own pace and take time to consider comments and responses rather than being "put on the spot" as in the physical classroom. Communication and relationships initially generated in the virtual environment can be brought into the classroom (McCarthy, 2010).

Facebook, currently the most used global social networking website, has not been widely used in tertiary education (McCarthy, 2010). Many scholars have suggested that Facebook and other Web 2.0 technologies may not always be appropriate or successful vehicles for formal teaching and learning activities (Lohnes \& Kinzer, 2007; Salaway, Caruso \& Nelson, 2007; Waycott, Bennett, Kennedy, Dalgarno \& Gray, 2010). However, integrating Facebook with blended learning in higher education seems to be a feasible means for teachers to enhance students' learning. Thus, to make full use of Web 2.0 technology, Facebook and peer assessment were integrated with blended learning in a semester-long English writing class for first-year students majoring in English, in a technological university, to explore its effectiveness and the students' perceptions towards this learning model.

\section{Literature review}

Recently, research has been increasingly inspired by social perspectives on learning. In particular, numerous studies on online learning are inspired by constructivist and social learning theories (Hrastinski, 2009). Since the 1990s, constructivism has made a strong influence on education, particularly in the field of instructional technology (Woo \& Reeves, 2007). Uzunboylu, Cavus and Ercag (2009) asserted that social constructivist theory assumes that students act and reflect within an environment, and this is then followed by reflecting, abstracting, and increasing experiential knowledge. On the other hand, Vygotsky (1978) focused more on the effects of social interaction, language, and culture on learning. Woo \& Reeves (2007) also stated that within the principles of the constructivist learning theory, meaningful interactions in a learning environment are designed to enhance meaning, including sharing various perspectives and experiences in communities of practice. Additionally, Birch and Volkov (2007) and Wilson and Stacey (2004) pointed out that the social constructivist paradigm focuses on learner-centred learning in which learners can share their knowledge, skills, experiences, and perspectives with each other. Students are encouraged to participate in active dialogue with other students and instructors and to collaborate with others in activities in order to construct knowledge and discover principles for themselves (Kearsley, 2011). Wang (2010) also reports that web-based learning has been supported by learning theories that emphasise the creation of an environment where learners can access and share knowledge and resources with one another. In this sense, web-based, technology-enhanced learning seems to be able to stimulate and support the learning process and enhance learning outcomes (Lee \& Woods, 2010).

The explosion and rapid development of Web 2.0 technologies, including audio and video podcasting, blogging, edublogs, social bookmarking, social networking, virtual world activities, and wiki writing, have led to increasing volumes of knowledge and learning opportunities that are suited to educational users and that stimulate the proliferation of virtual communities (Kennedy et al., 2007; Yang \& Chen, 2008; Gray, Thompson, Sheard, Clerehan \& Hamilton, 2010). Currently, social networking sites (SNSs) such as blogs, Facebook, MySpace, YouTube, Flickr and Twitter are among the most visited sites on the Internet, especially for Generation Y. Among these social networking sites, the features, interface, and popularity of Facebook make it an effective 
tool for easing primary obstacles to communication, such as language barriers and social inhibitions (McCarthy, 2010). In addition, the implementation of emerging Web 2.0 technologies can result in a positive impact on supporting students' learning processes and outcomes (Waycott \& Kennedy, 2009; McLoughlin \& Lee, 2008). Furthermore, technology-enhanced learning through web pages supports learners by such ways as facilitating and providing feedback or assessment, thereby reducing the effort expended on organisational issues and improving learning effectiveness (Shih, 2010).

The findings of recent studies show that online learning and instruction have positive impacts on language learning. For instance, Conroy (2010) concluded that Internetbased or assisted language learning could support college students in independent language learning and academic writing because these students are enthusiastic and reasonably competent users of Internet-based tools and techniques. In Internet-based instruction, elements such as emails, bulletin boards, chat rooms, and online discussions can promote learner-instructor and learner-learner interactions. Additionally, learner-content interactions and learning effects can be enhanced through online interactions such as multimedia presentations, learners' contributions to learning materials, and links to related learning materials (Lou, $\mathrm{Wu}$, Shih \& Tseng, 2010; Lou, Guyo, Zhu, Shih \& Dzan, 2011). Furthermore, according to Birch and Volkov (2007), online forums can encourage learners, in particular ESL students who may be reluctant to speak up in face to face settings, to engage in discussions. Online discussions can also contribute to assisting students in overcoming their linguistic limitations and expressing their own thoughts. Many studies have also found that team based or project based learning activities can promote active learning (Lang, 2010; Lou, Shih, Diez \& Tseng, 2010; Lou, Kiu, Shih \& Tseng, 2010; Neo, Neo \& Kwok, 2009). Technology can provide the potential for collaborative and cooperative learning, more learning opportunities, and means for learners to interact with each other and learn effectively.

According to Shih (2010), blended learning that integrates online and face to face instruction could create an effective teaching and learning experience for both instructors and students. Additionally, based on the results of the same study, blended learning can enhance students' motivation to participate actively in class. The interaction between teacher and students is important and may influence students' learning motivation and effectiveness (Derntl \& Motschnig-Pitrik, 2005; Hiltz \& Turoff, 2002). In addition, Liao (2006) pointed out that cooperative learning involves carefully structured activities for group members that allow students to reflect on and evaluate their work in the group while providing suggestions and comments for improvement. In the past few years, cooperative learning has received more attention and emphasis from the social constructivist perspective. Students are able to sustain the interrelationships among group members through effective group communication and discussions in this type of cooperative learning environment.

Many studies have shown that using online peer assessment can be effective for promoting students' performance and learning satisfaction and processes ( $\mathrm{Lu} \& \mathrm{Bol}$, 2007; Van Gennip, Segers \& Tillema, 2010; Xie, Ke \& Sharma, 2008; Xiao \& Lucking, 2008; Chang \& Chen, 2009; Van Gennip, Segers \& Tillema, 2009; Liang \& Tsai, 2010; Van Zundert, Sluijsmans \& Van Merrienboer, 2010; Shih, 2010). In addition, blended learning that combines online learning with face to face instruction can create a positive experience for both instructors and students and can facilitate online collaborative learning (So \& Brush, 2008; Shih, 2010). Furthermore, using online peer 
assessment as an alternative to face to face communication enhances learners' motivation, participation, and collaboration (Warschauer, 1996; Liang \& Tsai, 2010; Shih, 2010). Lee (2008) also pointed out that second language (L2) teachers should be aware of the influence of students' feedback practices on their expectations and attitudes. Through combining Web 2.0 technology, blended learning, and peer assessment, students are able to converse with each other, question each other, comment on each others' work and comments, and share opinions about various issues, which are aligned with the social constructivist theory.

In summary, pedagogy, technology, and social interaction are the key factors for a technology-enhanced learning environment. Thus, the author employed blended learning combining the Web 2.0 technology, Facebook, and online peer assessment with face to face instruction, which can be a new and feasible means for L2 teachers and learners to enhance their performance and satisfaction. The aim of this study is to explore how a blended learning approach, in particular involving the use of Facebook and online peer assessment, can affect the English writing skills of English majors.

\section{Methodology}

\section{Participants}

The participants of this study were 23 freshman (first year) English majors (18 females and 5 males) at a technological university in Taiwan. The 23 participants were divided into three categories (high score $=90$ points and above, medium score $=70$ - 89 points, and low score $=70$ points and below) according to their English subject scores on the National College Entrance Examination in 2010. There were 8 students in the high score group, 7 students in the medium score group, and 8 students in the low score group. Since commenting and assessing peers' writings can be very complicated and time consuming, each group was further divided into 2 groups for the Facebook integrated learning. Each group had a team leader responsible for applying for a Facebook account for the group and maintaining the site throughout the semester. Thus, a total of 6 Facebook sites for English writing were created. All group members were required to post their writing assignments on Facebook, assess the writings of other group members, and then provide them feedback and comments on Facebook weekly. All participants were also required to review and comment on other group members' feedback. A total of seven writing tasks were assigned to all of the participating students.

\section{Research instruments and research process}

A combination of qualitative and quantitative approaches was used in this study. The pre-test and post-test of English writing skills were given to all students at the beginning and in the last week of the semester, respectively. In both tests, the students were required to write an essay on a given topic. The scoring criteria used in this study were based on the five writing scoring criteria of National College Entrance Examination, including content, organisation, structure, vocabulary and spelling, and genre. In addition, the researcher adopted a 5-point Likert scale survey questionnaire initially developed by Hsieh (2010) and then modified and re-named it "Blended English Writing Course Satisfaction (BEWCS)." The modified questionnaire was validated by two senior professors in the field to establish its content validity. The five categories of the survey questionnaire were 1) course arrangement and implementation, 2) use of digital learning platform (Facebook), 3) interpersonal 
relationships, 4) English writing learning, and 5) learning satisfaction. Responses to the questionnaires were collected and computed by SPSS descriptive analysis. Content analysis was used to analyse the students' writings, feedback, and comments on Facebook. In addition, an in-depth interview consisting of three interview questions was conducted to understand the students' attitudes and perspectives towards this blended learning English writing course. Finally, the instructor's self-reflection was conducted. A sample webpage of the English Writing page on Facebook is presented in Figure 1.

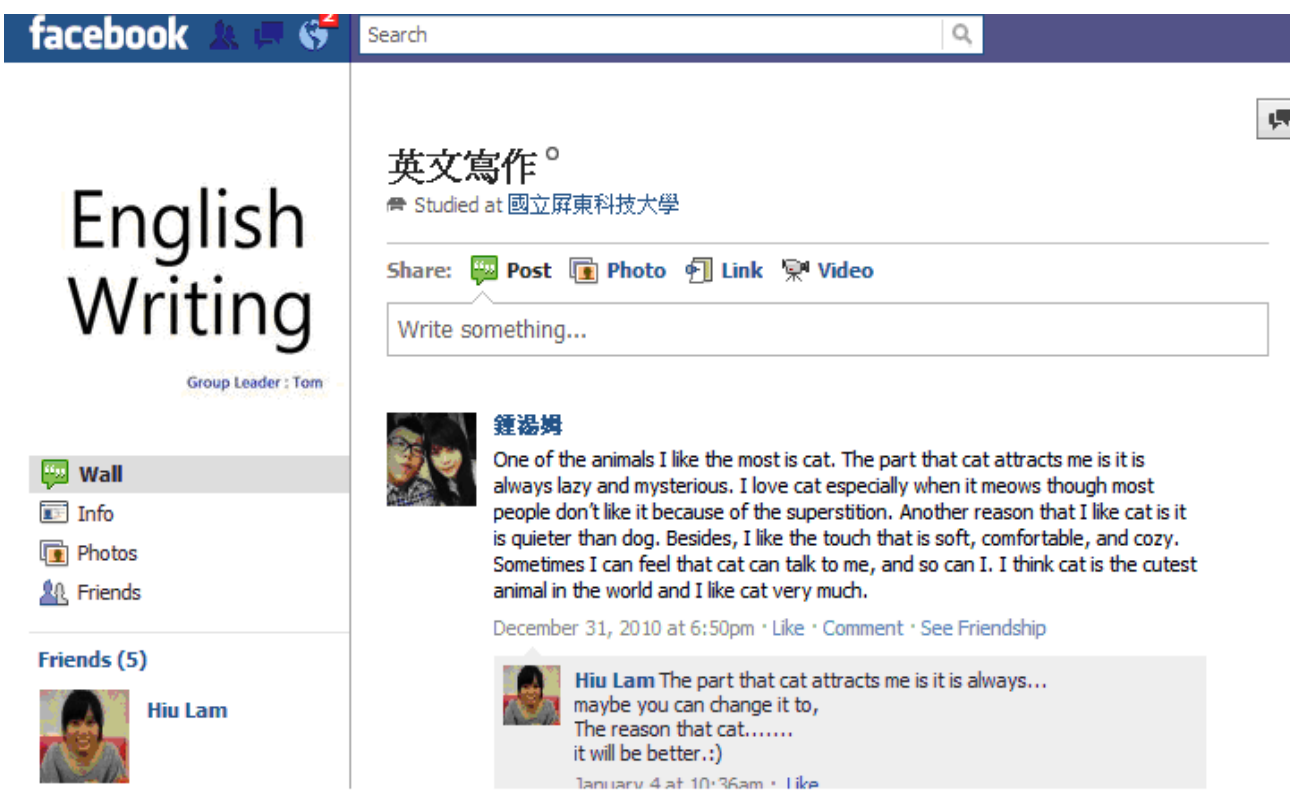

Figure 1: A sample webpage of the English Writing page on Facebook

\section{Interviews}

To obtain more in-depth information on the students' attitudes and levels of satisfaction towards this English writing blended learning course, interviews were conducted at the end of the semester. Six students volunteered to participate in the interviews. The interview questions used in the interviews were as follows:

1. What do you think of the course arrangement and implementation of the integrated Facebook blended learning approach for the English writing course?

2. What are the advantages and disadvantages of using Facebook to assist in learning English writing?

3. What are the advantages and disadvantages of using peer assessment to learn English writing?

\section{The implementation of the Facebook-integrated blended learning model}

The goal of this study was to explore how the Web 2.0 technology, Facebook, can be integrated with peer assessment and blended learning and the effect of this approach on learning outcomes. An English writing pre-test was administered during the 2nd week of the class. After the first six weeks of face-to-face learning, from the 9th week to the 16th week of the course, all students were divided into six groups (two groups each 
with high, medium, and low scores) based on their English scores on the National College Entrance Examination. Writing assignments were then posted on Facebook for the students to practise writing and giving comments. For each writing assignment, every student was required to post his or her own writing and comment on the works of others. The instructor encouraged the students to discuss, interact, and comment on other students' works as much as they could. The students were also encouraged to share knowledge and ideas related to the writing assignments. During this period, the instructor served as a facilitator and monitor evaluating and commenting on students' work and responses. In the 17th week, a post-test of English writing was administered. In the last week of the semester, the BEWCS survey and interviews were conducted. The implementation procedures of using Facebook-integrated blended learning for the English writing course are presented in Figure 2.

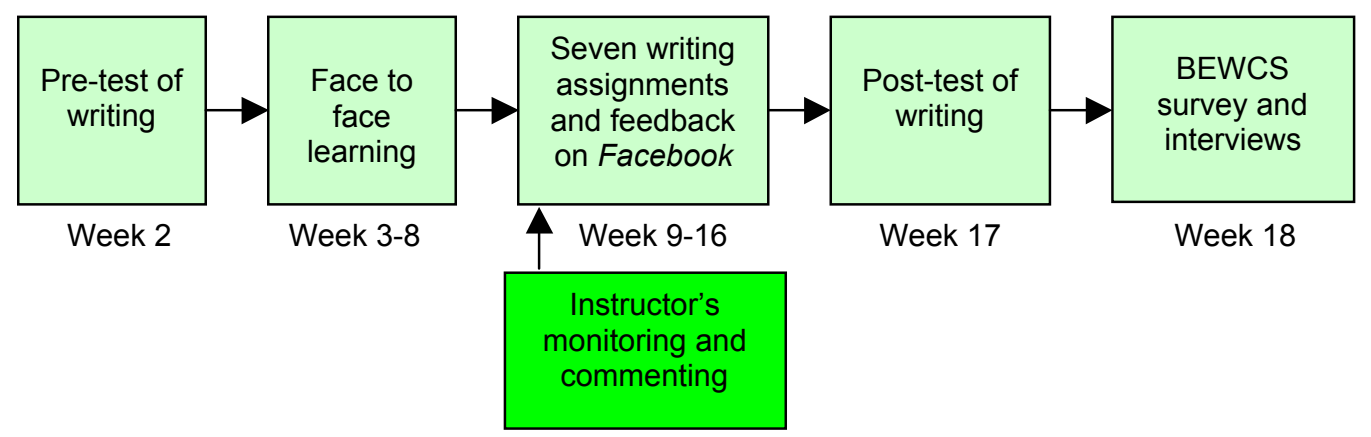

Figure 2: Implementation procedure for using Facebook-integrated blended learning

\section{Findings and discussion}

\section{Results of the pre-test and post-test of English writing}

The scores for the pre-test and post-test essays are presented in Table 1. For convenience in computing the scores, the two groups from each category were combined into one. Thus, there were three total groups (high score, medium score, and low score groups) for data analysis.

Table 1: Pre-test and post-test of English writing for the three combined groups

\begin{tabular}{|l|l|c|c|c|}
\hline \multirow{4}{*}{ Test } & & $\begin{array}{c}\text { Low score } \\
\text { group }(\mathrm{n}=8)\end{array}$ & $\begin{array}{c}\text { Medium score } \\
\text { group }(\mathrm{n}=7)\end{array}$ & $\begin{array}{c}\text { High score } \\
\text { group }(\mathrm{n}=8)\end{array}$ \\
\hline \multirow{4}{*}{$\begin{array}{l}\text { Pre-test } \\
\text { (Week } 2)\end{array}$} & Content & 20 & 20.5 & 23 \\
\cline { 2 - 5 } & Organisation & 20 & 20.5 & 22 \\
\cline { 2 - 5 } & Structure & 17 & 14.5 & 19.5 \\
\cline { 2 - 5 } & Vocabulary and spelling & 16.5 & 17 & 19 \\
\cline { 2 - 5 } & Genre & 8.5 & 7 & 9.5 \\
\cline { 2 - 5 } & Total & 82 & 79.5 & 93 \\
\hline \multirow{3}{*}{$\begin{array}{l}\text { Post-test } \\
\text { Week 17) }\end{array}$} & Content & 29 & 24.5 & 30 \\
\cline { 2 - 5 } & Organisation & 29.5 & 24 & 26 \\
\cline { 2 - 5 } & Structure & 24.5 & 21 & 23 \\
\cline { 2 - 5 } & Vocabulary and spelling & 23 & 18.5 & 11 \\
\cline { 2 - 5 } & Genre & 11 & 9 & 24.5 \\
\cline { 2 - 5 } & Total & 35 & 97 & $.001^{*}$ \\
\hline
\end{tabular}


Table 1 shows the statistical results of the pre-test and post-test of English writing for the three groups. Each of the three groups made significant progress on their post-tests $(p<.05)$ according to the results of paired $t$-tests of total scores. It is worth noticing that the low score group made the most progress of the three groups. The results support the proposition that Facebook-integrated blended learning for the English writing course was very effective.

\section{Content analyses of the Facebook writing assignments of the six groups}

From Week 9 to 15, the instructor required all of the students to write a short composition every week on their group Facebook site and to comment on others' writings. A total of seven writings were assigned. For convenience in the data analysis, the original six groups were combined into three groups (low, medium, and high score) to compare the frequencies of the students' comments and use of the "like" function to express appreciation for the works of others (Table 2).

Table 2: Frequencies of the students' comments and use of the "like" function

\begin{tabular}{|l|c|c|}
\hline \multicolumn{1}{|c|}{ Group } & $\begin{array}{c}\text { Frequency of } \\
\text { comments }\end{array}$ & $\begin{array}{c}\text { Frequency } \\
\text { of "like" }\end{array}$ \\
\hline Low score group (2 groups) & 114 & 38 \\
\hline Medium score group (2 groups) & 99 & 21 \\
\hline High score group (2 groups) & 135 & 57 \\
\hline Total & 348 & 116 \\
\hline
\end{tabular}

According to Table 2, the high score group members made 135 comments on and gave 57 "likes" to each other's writings, which represented the most frequent comment group with a per student average of 16.9 comments and 7.1 "likes". The next most frequent comment group was the low score group with 114 comments on and 38 "likes" to each other's writings resulting in an average of 14.2 comments and 4.8 "likes" per student. The medium score group made 99 comments on and gave 21 "likes" to each other's works, averaging 14.1 comments and and 3.0 "likes" per student.

From the instructor's observation and the content analysis of the comments, the high score group made the most frequent comments because they seemed to possess higher English competency and were therefore able to more readily find the errors in other's writings, to make comments and feedback. The performance on the pre-test and posttest and the frequency of comments made by the medium score group seemed less than expected. From the instructor's viewpoint, the group members' low learning motivation could explain this result, though there may be other reasons. Although the low score group made 114 comments, most of them repeated others' comments or gave incorrect suggestions. Figure 3 shows an example of the high score group students' assessment and comments on Facebook.

In addition, as shown in Table 2, the high score group members used the "like" function 57 times to support their comments, the medium score group used it 21 times, and the low score group used it 38 times. The students may have felt happy and encouraged by receiving the "like" icon on their writings. This was a sign for expressing peers' sense of appreciation and sympathy. The thumbs-up emoticon " "ז 1 person" is a Facebook feature that users can conveniently click to indicate that they like a status or comment. So students can choose to use this emoticon in addition to or in place of writing that they 'like' a peers' work. 


\section{Stephanie}

There are many kinds of animals in the world. Among all of the animals, I like hedgehogs the most. It is a kind of animal that looks like pineapple. And the most interesting thing is that their pineapple-like body will inflate and became bigger than usual when they feel dangerous or get angry. Then, they won't look like pineapples but durians! And I think that is the reason why I like them. How cool, aren't they?

December 29, 2010 at 6:01pm " Like " Comment - See Friendship

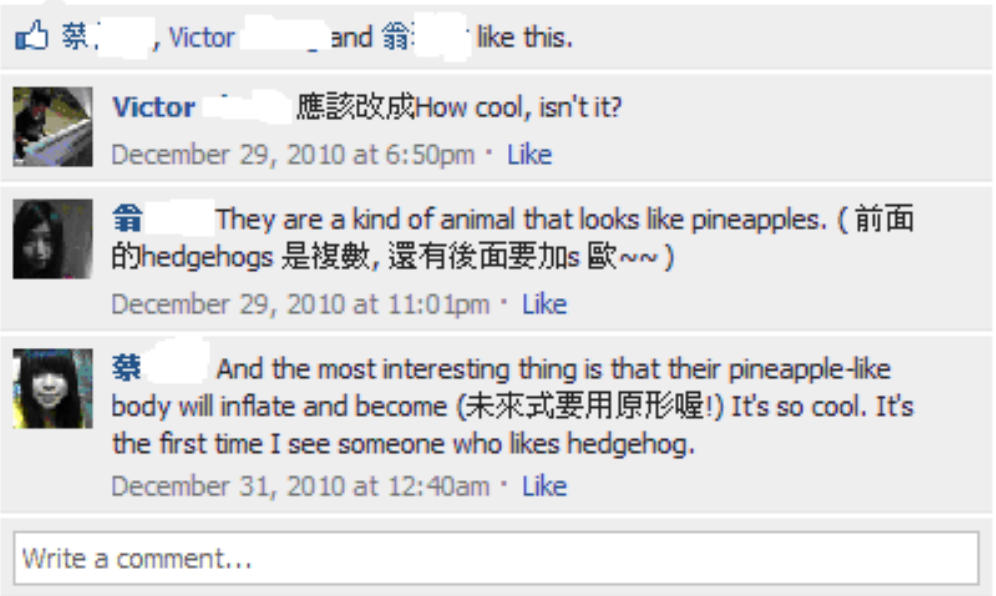

Figure 3: An example of the high score group students' comments on Facebook

Additionally, some comments would be added followed by emoticons (Figure 4). For example, if someone made an error in their writing, a peer could make a comment with “@@” to show they were confused or speechless, or they could follow a comment with ":-D" to show they were happy with the writing or to provide encouragement. Based on the content analysis of the students' comments on Facebook, the most frequently used emoticons were categorised into two types: appreciative or encouraging emoticons and sad or questioning ones (Table 3). Figure 4 shows examples of the students' comments with encouraging emoticons.

Table 3: A list of the most frequently used emoticons of the six groups on Facebook

\begin{tabular}{|c|c|c|c|c|c|c|c|c|c|}
\hline Type & \multicolumn{9}{|c|}{ Emoticons, from most (left) to least (right) frequently used } \\
\hline $\begin{array}{l}\text { Appreciation/ } \\
\text { encouraging }\end{array}$ & $\begin{array}{l}\text { ⿷'1 } 1 \\
\text { person }\end{array}$ & :) & $=)$ & :) & $:-\mathrm{D}$ & $\wedge \wedge$ & $=$ & rhaha & {$[!]$} \\
\hline $\begin{array}{l}\text { Sad/ } \\
\text { questioning }\end{array}$ & :) & @@ & $@ @ ?$ & $=\check{=}=$ & $=="$ & $:{ }^{\prime}($ & & & \\
\hline
\end{tabular}

Among the various emoticons used by the students to assist in commenting on other members' writings, some were encouraging and some indicated being sad or sorry. For instance, when students receive "like" "m 1 person" from others, they may be motivated and feel more confident. On the other hand, the sad or sorry emoticons might hurt a recipient's feelings. Therefore, the students not only gave comments to others but also added more positive emoticons to soften the tone of texts to make them more polite (Figure 4). Therefore, the students could benefit from peer comments and feedback without harming their friendships and relationships. 


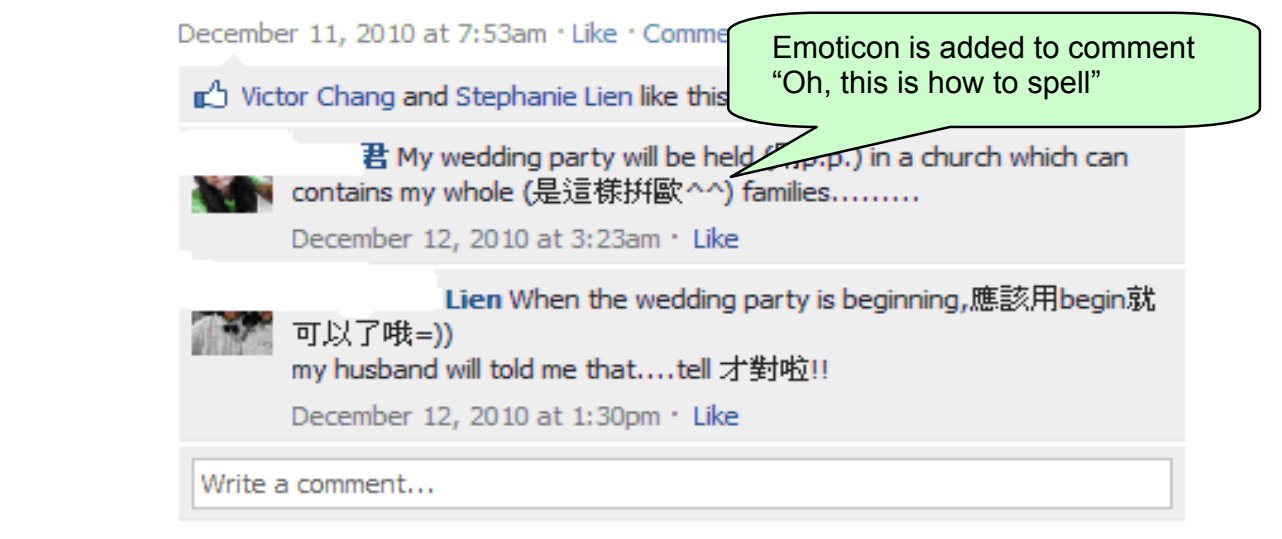

I'm now in Taipei. I want to go shopping, so I decide to take MRT to Ximending. I like to go there, because there are full of people. I think it will have more fun. I can walk around and see what I want to buy. But sometimes I can't make up my miind to choose things which is better. And then I go to Shiling night market in the evening. I can eat many delicious food. It is a wonderful day.

December 1, 2010 at 1:12am - Like - Comment - See Friendship

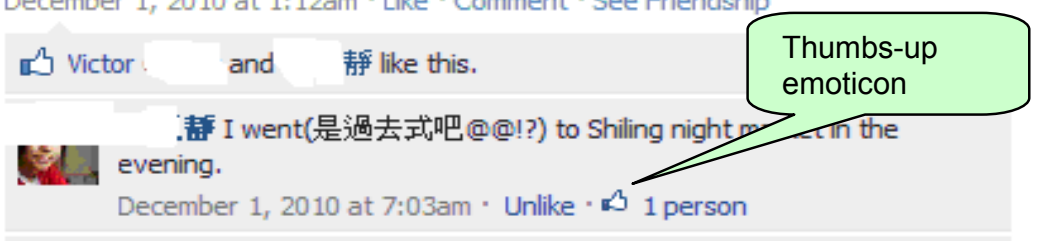

Figure 4: An example of student comments and encouraging emoticons

\section{Results of the responses to the BEWCS survey questionnaire}

The blended English writing course satisfaction (BEWCS) survey questionnaire was distributed to all students during the last week of class. A total of 22 valid questionnaires were returned and analysed. The survey questionnaires obtained a .928 Cronbach alpha coefficient, indicating the questionnaire had a high degree of internalconsistency reliability. The 30 items had mean scores ranging from 3.63 to 4.31 on a 5point Likert scale ( $5=$ strongly agree; $4=$ agree; $3=$ neutral; $2=$ disagree; $1=$ strongly disagree) with standard deviations ranging from .30 to .79 , indicating the students agreed or highly agreed with the statements on the survey questionnaire (Table 4). Additionally, the statistical results of a one-sample t-test show that all 30 items on the questionnaire had mean scores significantly higher than 3, indicating the students' attitudes and perspectives towards the Facebook-integrated English writing course were in moderately high consensus.

The statistics shown in Table 4 indicate that the students agreed that combining Facebook and peer assessment to evaluate and observe others' writings could highly enhance their learning. The results also show that cooperative learning could improve the students' communication, friendship, trust, interaction, active learning, and learning attitudes. Additionally, this Facebook-integrated blended learning approach could effectively assist the students' English learning organisation, grammar and structure, content, vocabulary, and spelling, although the students thought their 
assessment standards and criteria might be somewhat different from one another's. Furthermore, the students felt moderately fulfilled with this Facebook-integrated blended learning approach for the English writing course.

Table 4: Results for the 30 items on the survey questionnaire

\begin{tabular}{|c|c|c|c|}
\hline No & \begin{tabular}{|c|} 
Statement \\
\end{tabular} & Mean & SD \\
\hline 1 & Textbook was useful and its examples were practical. & 4.00 & .30 \\
\hline 2 & The teacher's guidance and assistance helped me in learning English writing. & 4.18 & .58 \\
\hline 3 & The course schedule and arrangement were appropriate. & 4.18 & .39 \\
\hline 4 & Cooperative learning made me put more effort into learning English writing. & 4.09 & .61 \\
\hline 5 & Cooperative learning made me learn how to solve problems. & 4.13 & .63 \\
\hline 6 & Reading others' writings and presenting their own thoughts benefited me a lot. & 4.27 & .55 \\
\hline 7 & Peer assessment increased my English writing ability. & 4.13 & .56 \\
\hline 8 & The blended learning approach for this class made me learn actively. & 4.09 & .29 \\
\hline 9 & In general, I was satisfied with this course arrangement and teaching methods. & 4.04 & .57 \\
\hline 10 & I was motivated to learn English writing on Facebook. & 4.13 & .56 \\
\hline 11 & Peer assessment on Facebook enhanced my critical thinking ability. & 4.27 & .63 \\
\hline 12 & Peer assessment of others' works enhanced cooperative learning. & 4.31 & .47 \\
\hline 13 & The features of Facebook, such as "like", stimulated my learning interest. & 3.86 & .71 \\
\hline 14 & In general, I was satisfied with the Facebook integrated blended learning. & 4.09 & .61 \\
\hline 15 & Cooperative learning helped me communicate with my teammates well. & 4.09 & .81 \\
\hline 16 & Cooperative learning increased the friendship between my teammates and me. & 4.13 & .35 \\
\hline 17 & Cooperative learning strengthened the trust between my teammates and me. & 3.90 & .61 \\
\hline 18 & Facebook made me actively assess others' work and share with others. & 4.13 & .56 \\
\hline 19 & My learning attitude became more serious through learning on Facebook. & 3.95 & .78 \\
\hline 20 & My interaction with teammates was enhanced through the Facebook platform. & 3.81 & .58 \\
\hline 21 & $\begin{array}{l}\text { I was able to learn more vocabulary and spelling through peer assessment on } \\
\text { Facebook. }\end{array}$ & 3.81 & .79 \\
\hline 22 & $\begin{array}{l}\text { I was able to learn English grammar and structure through peer assessment on } \\
\text { Facebook. }\end{array}$ & 4.18 & .50 \\
\hline 23 & I was able to learn organisation through peer assessment on Facebook. & 4.22 & .42 \\
\hline 24 & I could strengthen my content through pe & 4.00 & .53 \\
\hline 25 & The scoring standards between my teamn & 3.63 & .65 \\
\hline 26 & Combining Facebook with peer assessment enhanced my English writing skills. & 3.81 & .58 \\
\hline 27 & $\begin{array}{l}\text { Combining Facebook and peer assessment motivated my interest in English } \\
\text { writing. }\end{array}$ & 3.86 & .56 \\
\hline 28 & I am more confident in English writing after & 3.68 & .71 \\
\hline 29 & English writing & 3.81 & .73 \\
\hline 30 & I am satisfied that Facebook helped me learn English writing & 3.72 & .70 \\
\hline
\end{tabular}

To conclude, the students' attitudes and perspectives towards the implementation of this blended learning course as a whole were moderately to highly positive. In particular, the students showed high satisfaction with the course arrangement. Combining Facebook and peer assessment for the English writing course was highly appreciated by all the students. It was surprising that the feature of the "like" icon on Facebook could moderately stimulate the students' learning motivation for English writing. However, the use of emoticons could possibly enhance the group members' friendships or interpersonal relationships, based on the results of the survey questionnaire.

\section{Results of the interviews}

To obtain more in-depth information on the implementation of Facebook-integrated blended learning for the English writing course from the participants, six students 
from the six groups participated voluntarily in interviews. The six students' responses to the three interview questions were carefully recorded and coded by the researcher. A summary and some selected extracts from the students' responses to the three questions are presented below.

1. What do you think of the course arrangement and implementation of the integrated Facebook blended learning approach for the English writing course?

All of the students indicated that the most important factors for them to be motivated to learn English writing and find the class interesting were the instructor's teaching techniques, teaching enthusiasm, and sense of humour, which corroborated the statistical results of the high mean scores on survey questions 1 to 3 . Additionally, four students indicated that using Facebook in the English writing course was beneficial and helpful for them to learn English writing and to exchange opinions and ideas. Four students suggested that peer assessment could assist them in learning English writing and improve their writing skills. Finally, all of the students agreed that combining Facebook and peer assessment with the face to face instruction was an interesting and effective way for them to learn English writing. Excerpts of the students' interview responses are as follows:

I like the teaching way of class. The teacher uses an interesting way to teach us. (S2)

Facebook is convenient for each group to write paragraph on it... it's meaningful because members can exchange opinion. (S4)

2. What are the advantages and disadvantages of using Facebook to assist in learning English writing?

Regarding the advantages of using Facebook to assist in learning English writing, some students indicated that they were able to find writing mistakes and to correct them on Facebook. Additionally, it was much easier for them to learn from each other through posting writings on Facebook. Moreover, using Facebook to do assignments was convenient and reduced stress and environmental impact. Finally, using Facebook improved teamwork. However, the students also pointed out some disadvantages of using Facebook to learn English writing. Some reported that they sometimes forgot to do writing assignments on Facebook because they had too much fun on the Internet. Students also pointed out that writing online may result in bad habits with regard to vocabulary and spelling because they rely on the online correction tools too much. Some students also argued that they were not able to communicate well with their group members on Facebook and that it was not easy to write clear viewpoints or make clear comments on others' work because of the limitation on the number of characters on Facebook message board and limited English ability. Excerpts of the students' responses to Question 2 are as follows:

By using Facebook, I can learn the writing skills by reading my partner's essay...I think the way of discussing with members is very helpful for me. (S5)

We can read others' paragraphs and learn others' good points...we can also discuss some writing skills. (S4)

3. What are the advantages and disadvantages of using peer assessment to learn English writing? 
The majority of the students suggested that their peer's comments on and assessments of their English writing were very useful and beneficial. However, two students pointed out that some group members sometimes commented on their writings incorrectly because their understandings of grammar and sentence structure were not correct. This result is in accordance with the researcher's observations and experience in reviewing and commenting on the students' feedback on Facebook.

I can know which part of writing skills I should improve... I will examine my paragraph carefully in order not to make too many mistakes. (S5)

I can find my wrong grammars because of their comments...it can improve my English skill. From the interaction, we can know others' opinions to improve my writing. (S6)

I can find my fault, and I can also correct other classmates' paragraphs... I can learn more vocabularies, grammars from them. (S2)

Occasionally, the researcher found that some students made incorrect corrections to others' writings. Thus, this danger of using peer assessment in English writing courses should be taken into account.

To conclude, according to the students' responses to the interviews, using Facebook and peer assessment to assist in learning English writing for students seemed to be a suitable approach for ESL teachers. Facebook provided the students with opportunities to assess others' writings and improve their grammar, structure and content, organisation, and vocabulary. Peer assessment tasks were regarded as learning exercises in this study, and the students had greater opportunities than the instructor to observe their peers through this learning process and to obtain knowledge and skills from the writings, comments, and feedback of others. Furthermore, in the process of reviewing and commenting on their peers' work and offering comments and feedback, the students were able to modify their original work and improve its quality (Tsai \& Tseng, 2007). Thus, online peer assessment provided the students with additional chances to construct and refine their knowledge and skills through social interactions in a virtual environment. These findings are also consistent with the principle of social constructivism that meaningful interactions in a learning environment enhances sharing perspectives and experiences in communities of practice (Birch \& Volkov, 2007; Woo \& Reeves, 2007; Wilson \& Stacey, 2004; Vygotsky, 1978).

It is worth noting that false corrections by peers could be detrimental to peer assessment activities for an English writing course. Instructors should be aware of this issue when implementing peer assessment components in a course. The success of this blended learning course combining Facebook and peer assessment relied not only on a proactive course instructor involved and engaged in the students' comments and feedback, but also the students' full participation in the online writing activities. Facebook provided an excellent platform for displaying course information and a variety of resources for students to access freely. Its popularity, accessibility, and unique features attracted the students and eased their resistance to learning, making this a successful course.

\section{The instructor's reflection}

The instructor (the researcher) was a teacher, monitor, and facilitator in this study. During the online Facebook writing period, the instructor spent a great deal of time and 
effort in evaluating, correcting, examining, and responding to the students' comments, feedback, and assessments, which required a great workload and time commitment from the instructor. The instructor also needed to pay more attention to the students' writings and comments in terms of the presentations of grammatical errors, structure, and ideas. Meanwhile, the instructor had to be careful not to hurt the students' feelings and to always encourage the less-motivated students to write and assess one another's work. When a student made an incorrect assessment of another student's writing, the instructor would intervene and provide the correct comments; when the students did a good job assessing others' work, the instructor would also encourage them by using the "like" function to show appreciation and applause. Therefore, incorporating peer assessment into English writing courses could be more time-consuming for teachers than in other subjects.

\section{Conclusion and suggestions}

This study implemented a blended approach combining peer assessment on Facebook with face to face instruction for an English writing course for first year students in college. In this study, the peer assessment process on Facebook lasted approximately eight weeks, and the face to face instruction also lasted approximately eight weeks. Through this blended instructional approach, the students not only experienced and learned English writing skills and knowledge but also became more attentive and willing to express their own ideas in writing and more willing to interact with other people. Thus, the students' friendships, communication, and sense of trust were enhanced. The findings also suggest that the students were satisfied with this blended learning approach for the English writing course. However, the students also noted that the instructor's teaching methods were important in contributing to their satisfaction with the course.

In this study, the peer assessment process enabled the students to self-examine, review, observe, and make comments on each other's work and gain more detailed knowledge of each other's work. The survey results show that the students were able to improve their organisation, grammar and structure, content, vocabulary, and spelling. Thus, the use of peer assessment for English writing courses can be a feasible and effective approach. Students can continuously obtain relevant knowledge and skills through the peer assessment process. This online peer assessment could be implemented in other similar subjects in the future. Facebook also played an important role in this study. Without the convenience and popularity of the Facebook platform, the students would not have been so motivated to participate in the study or have enjoyed the learning process as much. Facebook also facilitated peer interaction successfully during the period of peer assessment. As a result, the findings of this study supported the social constructivist theory (Birch \& Volkov, 2007; Woo \& Reeves, 2007; Wilson \& Stacey, 2004; Vygotsky, 1978). That is, students can reflect, act, learn from each other, and construct meaningful knowledge and skills through collaborative learning and interaction (Uzunboylu, Cavus \& Ercag, 2009; Wang, 2008). The results of the study may also suggest that students with more sophisticated English writing abilities tend to have more interactions with other people and may therefore benefit more from the process of peer assessment.

To avoid students' resistance to peer assessment, instructors may have to provide a training session and appoint a group leader to guide and assist the teaching and learning interaction. Additionally, instructors of English writing courses should be 
willing to spend a substantial amount of time checking and correcting students' assignments and online peer comments. The major limitation of this study was the relatively small number of participants $(n=23)$. Future studies should involve larger numbers of students to be able to generalise the results. It would also be interesting to compare the effects among solely online instruction, Facebook-integrated blended learning, and face to face instruction of English writing courses. As the development and proliferation of Web 2.0 technologies make people more connected and provide access to more resources and information, investigating more effective strategies for English writing instruction becomes increasingly important for ESL educators.

\section{Acknowledgments}

The author gratefully acknowledges Dr Shi-Jer Lou, Professor, Graduate Institute of Technological and Vocational Education, and Dr Charles Papa, Department of Modern Languages, NPUST for their advice, support, and guidance in the development of this paper.

\section{References}

Birch, D. \& Volkov, M. (2007). Assessment of online reflections: Engaging English second language (ESL) students. Australasian Journal of Educational Technology, 23(3), 291-306. http: / / www.ascilite.org.au/ajet/ajet23/birch.html

Chang, T. Y. \& Chen, Y. T. (2009). Cooperative learning in e-learning: A peer assessment of student-centered using consistent fuzzy preference. Expert Systems with Applications, 36(4), 8342-8349. http: / / dx.doi.org/10.1016/j.eswa.2008.10.050

Cheung, W. S. \& Hew, K. F. (2010). Examining facilitators' habits of mind in an asynchronous online discussion environment: A two cases study. Australasian Journal of Educational Technology, 26(1), 123-132. http:/ / www.ascilite.org.au/ ajet/ ajet26/ cheung.html

Conroy, M. A. (2010). Internet tools for language learning: University students taking control of their writing. Australasian Journal of Educational Technology, 26(6), 861-882.

http: / / www.ascilite.org.au/ajet/ajet26/ conroy.html

Derntl, M. \& Motschnig-Pitrik, R. (2005). The role of structure, patterns, and people in blended learning. The Internet and Higher Education, 8(2), 111-130. http: / /dx.doi.org/10.1016/j.iheduc.2005.03.002

Facebook (2011). Statistics: People on Facebook. [viewed 30 Jun 2011]. https:/ / www.facebook.com/press/info.php?statistics

Gray, K., Thompson, C., Sheard, J., Clerehan, R. \& Hamilton, M. (2010). Students as Web 2.0 authors: Implications for assessment design and conduct. Australasian Journal of Educational Technology, 26(1), 105-122. http:/ / www.ascilite.org.au/ ajet/ ajet26/gray.html

Hiltz, S. R. \& Turoff, M. (2002). What makes learning networks effective? Communications of the ACM, 45(4), 56-59. http: / / dx.doi.org/10.1145/505248.505273

Hrastinski, S. (2009). A theory of online learning as online participation. Computers $\mathcal{E}$ Education, 52(1), 78-82. http:/ / dx.doi.org/10.1016/j.compedu.2008.06.009

Kearsley, G. (2011). The Theory Into Practice Database. http: / tip.psychology.org 
Kennedy, G., Dalgarno, B., Gray, K., Judd, T., Waycott, J., Bennett, S., et al. (2007). The net generation are not big users of Web 2.0 technologies: Preliminary findings. In ICT: Providing choices for learners and learning. Proceedings ascilite Singapore 2007 (pp. 517-525). http: / / www.ascilite.org.au/conferences/singapore07/procs/kennedy.pdf

Quek, C. L. (2010). Analysing high school students' participation and interaction in an asynchronous online project-based learning environment. Australasian Journal of Educational Technology, 26(3), 327-340. http:/ / www.ascilite.org.au/ ajet/ ajet26/ quek.html

Lee, L (2008). Focus-on-form through collaborative scaffolding in expert-to-novice online interaction. Language Learning \& Technology, 12(3), 53-72.

Lee, S. E. \& Woods, K. J. (2010). Using contemporary topics and Internet resources to stimulate student-centred learning. Australasian Journal of Educational Technology, 26(6), 775-790. http: / / www.ascilite.org.au/ajet/ajet26/lee.html

Liang, J. C. \& Tsai, C. C. (2010). Learning through science writing via online peer assessment in a college biology course. The Internet and Higher Education, 13(4), 242-247. http:/ / dx.doi.org/10.1016/j.iheduc.2010.04.004

Lohnes, S. \& Kinzer, C. (2007). Questioning assumptions about students' expectations for technology in college classrooms. Innovate, 3(5), http: / / www.innovateonline.info/index.php? view=article\&id $=431$

Lou, S. J., Guo, Y. C., Zhu, Y. Z., Shih, R. C. \& Dzan, W. Y. (2011). Applying computer-assisted musical instruction to music appreciation course: An example with Chinese musical instruments. The Turkish Online Journal of Educational Technology, 10(1), 45-57. http: / / www.tojet.net/articles / 1015.pdf

Lou, S. J., Wu, S. C., Shih, R. C. \& Tseng, K. H. (2010). Adoption of blogging by a Chinese language composition class in a vocational high school in Taiwan. Australasian Journal of Educational Technology, 26(6), 898-916. http: / / www.ascilite.org.au/ajet/ajet26/lou.html

Lou, S. J., Shih, R. C., Diez, C. R. \& Tseng, K. H. (2010a). The impact of problem-based learning strategies on STEM knowledge integration and attitudes: an exploratory study among female Taiwanese senior high school students. International Journal of Technology and Design Education, 21(2), 195-215. http:/ / dx.doi.org/10.1007/s10798-010-9114-8

Lou, S. J., Liu, Y. H., Shih, R. C. \& Tseng, K. H. (2010b). The senior high school students' learning behavioral model of STEM in PBL. International Journal of Technology and Design Education, 21(2), 161-183. http: / / dx.doi.org/10.1007/ s10798-010-9112-x

Lu, R. \& Bol, L. (2007). A comparison of anonymous versus identifiable e-peer review on college student writing performance and the extent of critical feedback. Journal of Interactive Online Learning, 6(2), 100-115. http: / / www.ncolr.org/jiol/issues / pdf/6.2.2.pdf

McCarthy, J. (2010). Blended learning environments: Using social networking sites to enhance the first year experience. Australasian Journal of Educational Technology, 26(6), 729-740. http:/ / www.ascilite.org.au/ajet/ajet26/mccarthy.html

McLoughlin, C. \& Lee, M. J. W. (2008). Mapping the digital terrain: New media and social software as catalysts for pedagogical change. In Hello! Where are you in the landscape of educational technology? Proceedings ascilite Melbourne 2008.

http:/ / www.ascilite.org.au/conferences/melbourne08/procs/mcloughlin.pdf

Moore, K. \& Iida, S. (2010). Students' perception of supplementary, online activities for Japanese language learning: Groupwork, quiz and discussion tools. Australasian Journal of Educational Technology, 26(7), 966-979. http: / / www.ascilite.org.au/ajet/ajet26/moore.html 
Neo, T. K., Neo, M. \& Kwok, W. J. (2009). Engaging students in a multimedia cooperative learning environment: A Malaysian experience. In Same places, different spaces. Proceedings ascilite Auckland 2009. http:www.ascilite.org.au/conferences/auckland09/procs/neo.pdf

Preston, G., Phillips, R., Gosper, M., McNeill, M., Woo, K. \& Green, D. (2010). Web-based lecture technologies: Highlighting the changing nature of teaching and learning. Australasian Journal of Educational Technology, 26(6), 717-728. http:/ / www.ascilite.org.au/ajet/ajet26/ preston.html

Salaway, G., Caruso, J. \& Nelson, M. (2007). The ECAR study of undergraduate students and information technology, 2007. Boulder, Colorado: EDUCAUSE Center for Applied Research. http: / / www.educause.edu/ECAR/TheECARStudyofUndergraduateStu/ 161967

Sheard, J., Carbone, A. \& Hurst, A. J. (2010). Student engagement in first year of an ICT degree: Staff and student perceptions. Computer Science Education, 20(1), 1-16. http: / / dx.doi.org/10.1080/08993400903484396

Shih, R. C. (2010). Blended learning using video-based blogs: Public speaking for English as second language students. Australasian Journal of Educational Technology, 26(6), 883-897. http: / / www.ascilite.org.au/ajet/ajet26/shih.html

So, H. J. \& Brush, T. A. (2008). Student perceptions of collaborative learning, social presence and satisfaction in a blended learning environment: Relationships and critical factors. Computers E Education, 51(1), 318-336. http:/ / dx.doi.org/10.1016/j.compedu.2007.05.009

Stacey, E. (2002). Learning links online: Establishing constructivist and collaborative learning environments. In S. McNamara \& E. Stacey (Eds.), Untangling the web: Establishing learning links. Proceedings ASET Conference 2002. Melbourne, 7-10 July. http: / / www.ascilite.org.au / aset-archives / confs / 2002 / stacey.html

Tseng, S. C. \& Tsai, C. C. (2007). On-line peer assessment and the role of the peer feedback: A study of high school computer course. Computers $\mathcal{E}$ Education, 49(4), 1161-1174. http:/ / dx.doi.org/10.1016/j.compedu.2006.01.007

Uzunboylu, H., Cavus, N. \& Ercag, E. (2009). Using mobile learning to increase environmental awareness. Computers \& Education, 52(2), 381-389. http: / / dx.doi.org/10.1016/j.compedu.2008.09.008

Van Gennip, N. A. E., Segers, M. S. \& Tillema, H. H. (2010). Peer assessment as a collaborative learning activity: The role of interpersonal variables and conceptions. Learning and Instruction, 20(4), 280-290. http:/ / dx.doi.org/10.1016/j.learninstruc.2009.08.010

Van Gennip, N. A. E., Segers, M. S. \& Tillema, H. H. (2009). Peer assessment for learning from a social perspective: The influence of interpersonal variables and structural features. Educational Research Review, 4(1), 41-54. http: / / dx.doi.org/10.1016/j.edurev.2008.11.002

Van Zundert, M., Sluijsmans, D. \& Van Merrienboer, J. (2010). Effective peer assessment processes: Research findings and future directions. Learning and Instruction, 20(4), 270-279. http: / / dx.doi.org/10.1016/j.learninstruc.2009.08.004

Wang, Q. (2008). A generic model for guiding the integration of ICT into teaching and learning. Innovations in Education and Teaching International, 45(4), 411-419. http: / / dx.doi.org/10.1080/14703290802377307

Wang, M. J. (2009). Web based projects enhancing English language and generic skills development for Asian hospitality industry students. Australasian Journal of Educational Technology, 25(5), 611-626. http:/ / www.ascilite.org.au/ajet/ajet25/wang.html 
Waycott, J. \& Kennedy, G. (2009). Mobile and Web 2.0 technologies in undergraduate science: Situating learning in everyday experience. In Same places, different spaces. Proceedings ascilite Auckland 2009. http: / / www.ascilite.org.au/ conferences / auckland09/ procs / waycott.pdf

Waycott, J., Bennett, S., Kennedy, G., Dalgarno, B. \& Gray, K. (2010). Digital divides? Student and staff perceptions of information and communication technologies. Computers $\mathcal{E}$ Education, 54(4), 1202-1211. http: / / dx.doi.org/10.1016/j.compedu.2009.11.006

Wilson, G. \& Stacey, E. (2004). Online interaction impacts on learning: Teaching the teachers to teach online. Australasian Journal of Educational Technology, 20(1), 33-48. http: / / www.ascilite.org.au/ajet/ajet20/ wilson.html

Woo, Y. \& Reeves, T. C. (2007). Meaningful interaction in web-based learning: A social constructivist interpretation. The Internet and Higher Education, 10(1), 15-25. http: / / dx.doi.org/10.1016/j.iheduc.2006.10.005

Xiao, Y. \& Lucking, R. (2008). The impact of two types of peer assessment on students' performance and satisfaction within a Wiki environment. The Internet and Higher Education, 11(3-4), 186-193. http: / / dx.doi.org/10.1016/j.iheduc.2008.06.005

Xie, Y., Ke, F. \& Sharma, P. (2008). The effect of peer feedback for blogging on college students' reflective learning process. The Internet and Higher Education, 11(1), 18-25. http:/ / dx.doi.org/10.1016/j.iheduc.2007.11.001

Yang, S. J. H. \& Chen, I. Y. L. (2008). A social network-based system for supporting interactive collaboration in knowledge sharing over peer-to-peer network. International Journal of Human-Computer Studies, 66(1), 36-50. http:/ / dx.doi.org/10.1016/j.ijhcs.2007.08.005

Author: Dr Ru-Chu Shih, Assistant Professor, Department of Modern Languages National Pingtung University of Science and Technology 1 Shuefu Road, Neipu, Pingtung 912, Taiwan. Email: vincent@npust.edu.tw

Please cite as: Shih, R.-C. (2011). Can Web 2.0 technology assist college students in learning English writing? Integrating Facebook and peer assessment with blended learning. In J. Waycott \& J. Sheard (Eds), Assessing students' Web 2.0 activities in higher education. Australasian Journal of Educational Technology, 27(Special issue, 5), 829845. http:/ / www.ascilite.org.au/ajet/ajet27/ shih.html 